\title{
Effect of dripline depth on the agronomic parameter of eggplant Solanum melongena L. (Solanaceae)
}

\section{Hiba Ghazouani ${ }^{1,}$, , Boutheina M'hamdi Douh ${ }^{1}$, Basma Latrech ${ }^{1}$, Mguidich Belhaj Amel ${ }^{2}$, Ghazouani Issam $^{3}$ and Abdelhamid Boujelben ${ }^{1}$}

${ }^{1}$ Department of Rural Engineering. Higher Institute of Agronomy. Chott-Mariem Sousse (ISA-CM). Université de Sousse, 4042. Tunisia. *Email: ghazouani_hibaunipaisa@yahoo.com.

${ }^{2}$ Regional Field Crops Research Center (CRRGC). Béja. Tunisia.

${ }^{3}$ University of Jendouba. Higher School of Agriculture of Kef. Kef. Tunisia.

\begin{abstract}
Despite numerous researches investigated on subsurface drip irrigation (SDI), local information about the response of eggplant growth and water dynamics on SDI still very limited in Tunisia. Results showed that lower values of soil water contents were obtained under traditional drip irrigation (DI) treatment, as a consequence of higher evaporative demand. Leaf area, the number of fruits per plant, as well as the crop yield obtained on SDI treatment, resulted significantly higher $(\mathrm{P}=0.05)$ than the corresponding measured on DI treatment. The better performance associated to SDI compared to DI, was due to the minor evaporation losses from the soil surface and consequently higher irrigation water use efficiency. When the drip laterals were buried, the wet bulbs in the soil induced the concentration of roots around the points where water is applied. Moreover, the occurrence of capillary rise could contribute to a redistribution of water stock around zones of active roots.
\end{abstract}

Keywords: Plant height; Fruit number; Leaf area; Yield; Water contents.
Received April 6, 2019

Accepted

April 29, 2019

Released April 30, 2019

Full Text Article

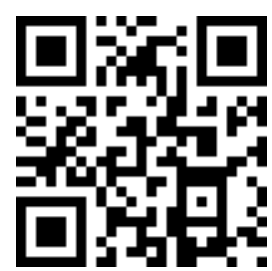

ORCID

() 0000-0002-4601-1528 Ghazouani Hiba

(ㄱ) 0000-0002-3439-2212

Boutheina M'hamdi Douh

D) 0000-0002-5790-0558 Basma Latrech

(1) 0000-0002-1223-5312 Mguidich Belhaj Amel

(1) 0000-0002-7797-2671 Ghazouani Issam

D 0000-0002-3026-9014 Abdelhamid Boujelben 


\section{Introduction}

While scarcity of water resources is an intrinsic feature of the climate of the Maghreb countries, this phenomenon is accentuating in the recent decades, with more frequent drought period. Tunisia is characterized by a semi-arid climate marked by irregular precipitations in time and space. Therefore, rainfed system could no longer satisfy crops water needs and ensure stable and sufficient agricultural production, hence the use of irrigation to prevent hazardous effect of climate change is becoming more and more crucial (Mailhol, 2005).

Furrow and sprinkler are the most commonly used irrigation systems for potato crop. Advanced in plastic manufacturing technology, associated to improved reliability and reduced installation costs have recently determined, even in Tunisia, the widespread use of drip irrigation systems for intensive horticultural crops, and in few cases by means of subsurface applications.

Surface or subsurface drip systems, with dispensing pipes placed on the soil surface or buried in the ground, are considered very effective irrigation methods. Since the introduction of coextruded pipes, with emitters welded in during the manufacturing process, subsurface drip irrigation (SDI) has been considered the most advanced method of irrigation. These systems provide the application of small amounts of water to the soil through emitters installed below the soil surface, with discharge rates generally in the same range as surface drip irrigation (ASAE, 2005). Under SDI, only a limited soil volume around the emitter is wetted: water flows in a small cavity near the outlet and then infiltrates into the soil (Dukes et al., 1995). Many advantages are associated to SDI compared to traditional drip irrigation (DI), such as reduction of evaporation losses, deep percolation and surface runoff (Camp, 1998). Moreover, a longer system life is ensured being the dispensing line not exposed to sun and external weather conditions.

By comparing DI and SDI, Ruskin (2000) found that the latter systems allow water savings up to $46 \%$ in medium and heavy textured soils, in which capillary actions are the main driving forces of water movement. After 10 years of researches on corn production, Lamm and Trooien (2003) underlined that horticultural crops on shallow or coarse textured soils tend to respond more positively to frequent irrigation events, also stating that to achieve the best management practice, irrigation events have to be limited to replace approximately $75 \%$ of cumulated crop evapotranspiration. SDI systems can be effective under saline or brackish water in order to prevent major problems, such as direct contact of saline waters with salt sensitive plant tissues or health problems caused by pathogens in the water.

The objective of the paper is to investigate of the effect of subsurface drip irrigation system (SDI), in a comparison to drip irrigation DI, on temporal evolution of water contents and agronomic parameters of Eggplant.

\section{Materials and methods}

The research was carried out, from April to June 2007, at the experimental site of "Higher Agronomic Institute of Chott Meriem in Sousse, Tunisia (Longitude $10.5604^{\circ} \mathrm{E}$, Latitude $35.9130^{\circ} \mathrm{N}$, altitude $15 \mathrm{~m}$ a.s.l.). The experimental plot was divided in two 25 $\mathrm{m}$ large and $40 \mathrm{~m}$ long subplots in which eggplants Solanum melongena $\mathrm{L}$. (Solanaceae) were planted with spacing between the rows of $1.2 \mathrm{~m}$ and along the rows of 0.40 . The first sub-plot was irrigated by means of traditional drip irrigation (DI) with laterals laid on the 
soil surface, whereas the second was irrigated with a subsurface drip irrigation (SDI) system, with laterals installed at $0.20 \mathrm{~m}$ below the soil surface. Emitters in co-extruded laterals were spaced $40 \mathrm{~cm}$ and characterized by a flow rate of $2.0 \mathrm{~L} \mathrm{~h}^{-1}$ at a nominal pressure of $100 \mathrm{kPa}$.

In order to estimate reference evapotranspiration, ET0, meteorological standard variables (air temperature, humidity, global radiation, precipitation and wind speed at $2 \mathrm{~m}$ ) were acquired from a weather station installed about $300 \mathrm{~m}$ far from the experimental site. Daily values of ET0 were determined according to modified FAO PenmanMonteith equation (Allen et al., 1998). FAO "single crop approach" was then used for maximum evapotranspiration. Spatial and temporal variability of soil water contents was acquired with a Time Domain Reflectometry (TDR) probe, (Trime-FM3, IMKO Micromodultechnik $\mathrm{GmbH}$, Germany). The sensor, inserted in plastic access tubes preventively installed in the soil, allowed to measure volumetric water contents of a soil volume with diameter and height equal to about $15 \mathrm{~cm}$. A total of four access tubes $70 \mathrm{~cm}$ long were installed in each sub-plot, along the direction perpendicular to the plant row at distances of $0 \mathrm{~cm}, 20 \mathrm{~cm}, 40 \mathrm{~cm}$ and 60 $\mathrm{cm}$ from the emitter; soil water contents were regularly measured during the investigation period at depths of $15 \mathrm{~cm}$, $30 \mathrm{~cm}$ and $45 \mathrm{~cm}$. Irrigation water was supplied, taking into account the rainfall events, every 7-10 days at the beginning of the crop cycle (March and April) and approximately once a week during the crop full development stage and harvesting (May and June), for a total of 15 watering of $1 \mathrm{~h}$.

\section{Result and discussion}

\section{Agroclimatic characterization of the study area}

The dynamic of rainfall, irrigation, reference evapotranspiration and maximum evapotranspiration, measured during the growing season 2007, is shown in Figure 1. For the considered period, daily values of ET0 increased, according to the climatic conditions, from $2.0 \mathrm{~mm} \mathrm{~d}^{-1}$ at the end of February to about $4.0 \mathrm{~mm} \mathrm{~d}^{-1}$, at the end of June. Precipitations events occurred till the end of April, with the exception of two insignificant events in May. Irrigation scheduling followed the ordinary management practiced in the surrounding area, with a total depth, provided from February 17, equal to about $115 \mathrm{~mm}$ divided in 15 watering. During the growing season the total precipitation height resulted equal to $120 \mathrm{~mm}$. Moreover, As can be observed, ETm tends to increase during the growing season, from mid of March to the end of June, rising from $0.4 \mathrm{~mm} \mathrm{~d}^{-1}$ to about $4.0 \mathrm{~mm} \mathrm{~d}^{-1}$, according to of ET0 and Kc. During the full development stage, daily values of ETm resulted variable between 3 and $4 \mathrm{~mm} \mathrm{~d}^{-1}$, according to the variability of ET0.

\section{Soil characterization}

Table 1 summarizes soil characteristics of the three layers of the soil profile. As can be observed, the soil presents a sandy loam texture with the lower bulk density and the higher saturated hydraulic conductivity at the top layer of the soil profile. These results could be attributed to the plowing phenomena and soil compaction. 


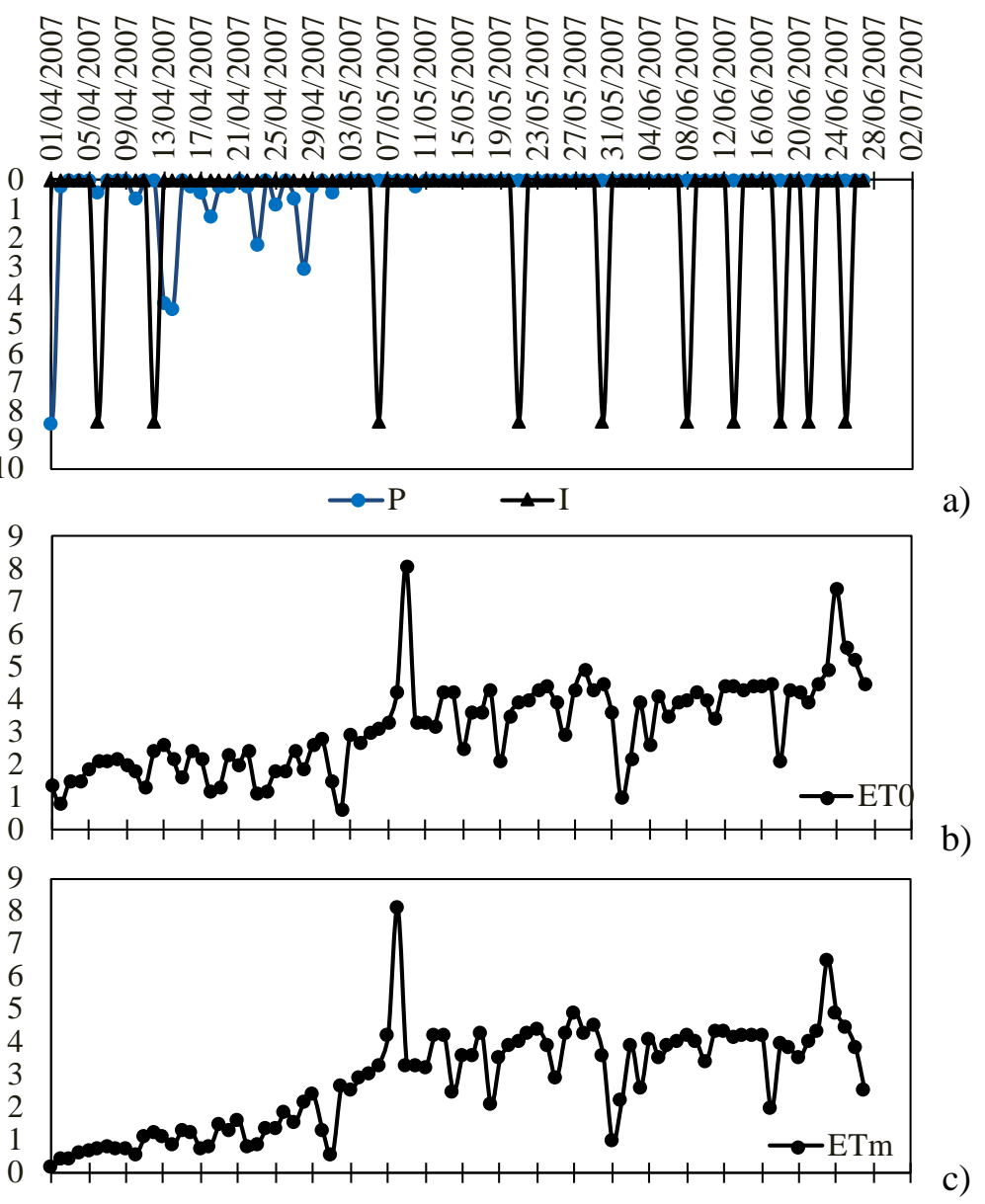

Figure 1. Temporal trends of precipitation and irrigation (a), reference evapotranspiration (b) and maximum evapotranspiration (c).

Table 1. Soil characterization of the investigated site.

\begin{tabular}{|c|c|c|c|c|c|c|c|}
\hline \multirow[b]{2}{*}{ Sample } & \multirow[b]{2}{*}{ Depth } & \multicolumn{3}{|c|}{ Textural composition } & \multirow[b]{2}{*}{ Soil Texture } & \multirow{2}{*}{ Bulk density } & \multirow{2}{*}{$\begin{array}{c}\text { Hydraulic conductivity at } \\
\text { saturation, } \mathrm{Ks}\end{array}$} \\
\hline & & Clay & Limon & Sand & & & \\
\hline & {$[\mathrm{cm}]$} & [\%] & [\%] & [\%] & & {$\left[\mathrm{g} \mathrm{cm}^{-3}\right]$} & {$\left[\mathrm{cm} \mathrm{h}^{-1}\right]$} \\
\hline $0-20$ & 15 & 17.64 & 14.30 & 68.06 & Sandy loam & 1.27 & 11.0 \\
\hline $20-40$ & 30 & 17.26 & 15.89 & 66.85 & Sandy Loam & 1.43 & 6.4 \\
\hline $40-60$ & 60 & 17.90 & 15.24 & 66.86 & Sandy loam & 1.47 & 3.8 \\
\hline
\end{tabular}

\section{Soil water content}

Figure 2 shows the dynamic of precipitation plus irrigation and average soil water content for DI and SDI. As can be observed, the depth of the drip line plays a major role for water content distribution. In fact, in the treatment, where the drip line was laid on top surface (DI), average soil water content resulted lower. 

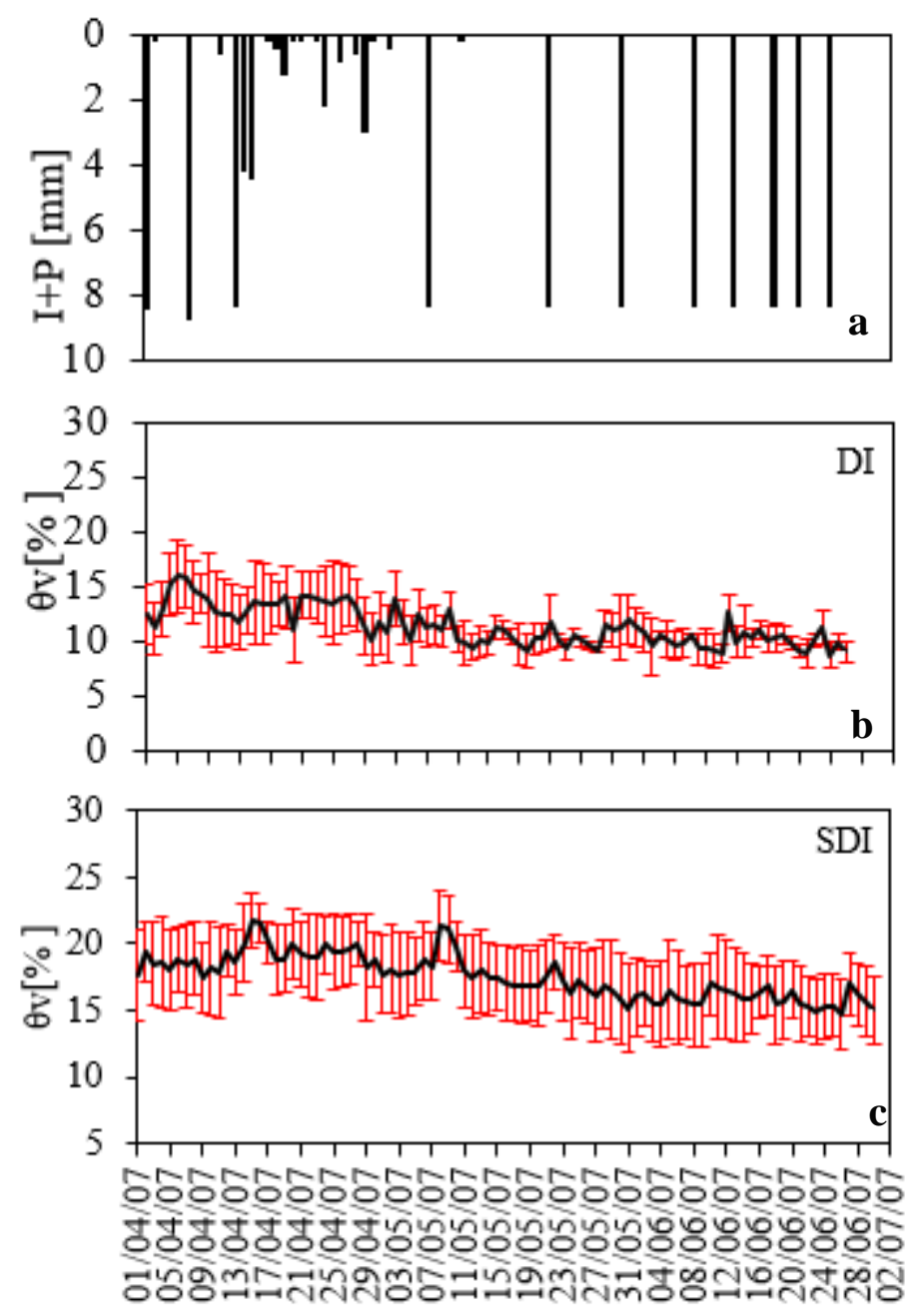

Figure 2. Temporal dynamic of Irrigation plus precipitation (a) and of soil water contents for DI (b) and SDI treatment (c).

Figure 3 shows the effects of drip line installation depth on crop parameters of eggplant crop, such as plant height from the seventh to the twelfth week after plantation, leaf area, fruit number at harvesting and finally, crop yield. As can be noticed, even if the seasonal irrigation volume was the same in both DI and SDI treatments, the considered agronomic parameters during and at the end of growth seasons were affected by the position of the laterals. 

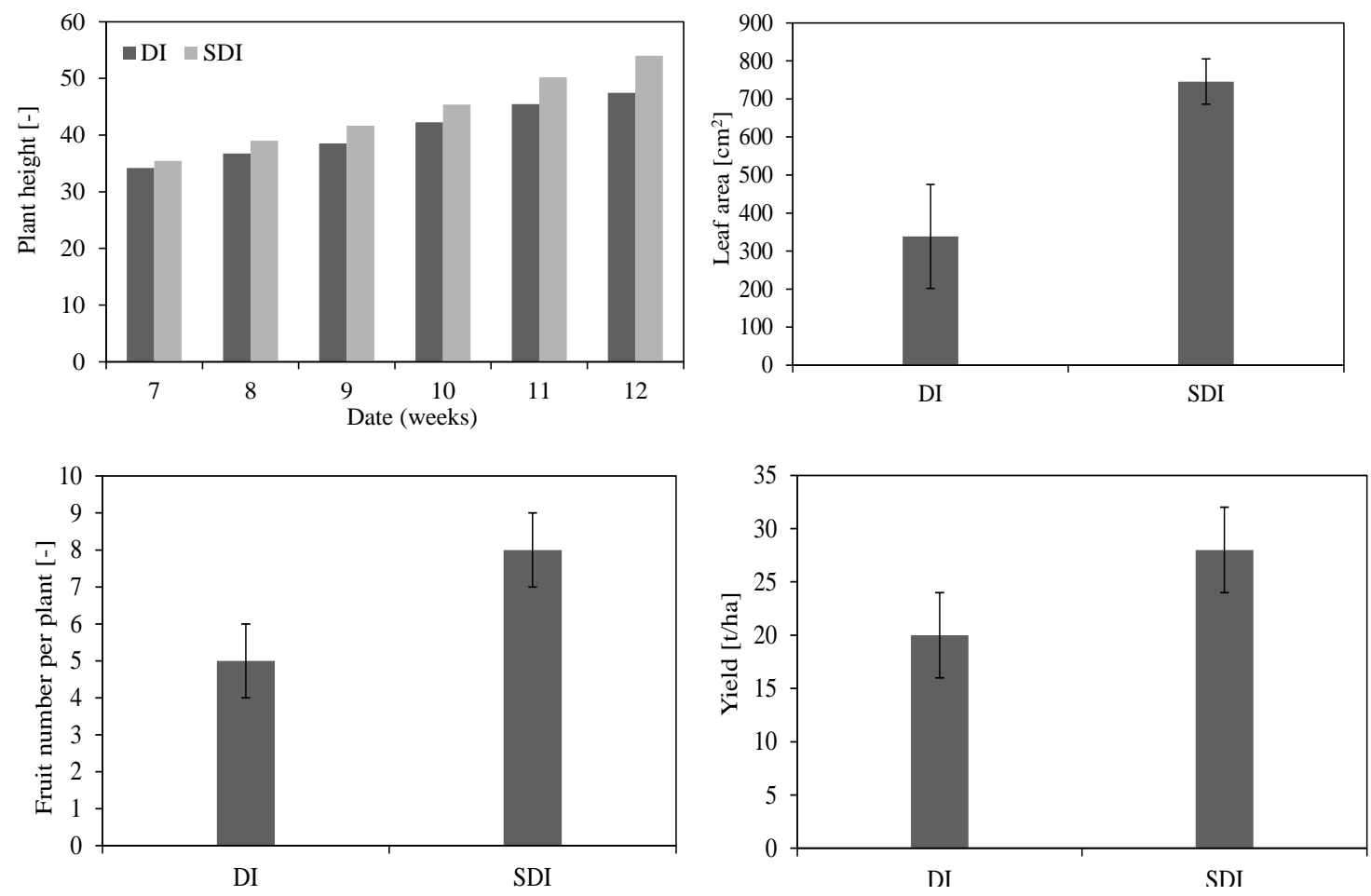

Figure 3. Effects of drip line position on agronomic parameters of eggplant crop.

\section{Discussion}

When is the case of soil water contents, it was observed that lower values were attributed to DI treatment. These lower values were mainly related to the importance of the evaporation. Furthermore, the crop cycle of eggplants coincided with a period of high atmospheric demand and low precipitations (Figure 1). In treatment of SDI, the water reaches deeper layers so the capillary rise processes will increase and modify the distribution of soil water stock. In that context, Douh and Boujelben (2007) have tested pop corn crop on the same area of the semi-arid climate of the Tunisian environment and found that Subsurface drip irrigation buried at $35 \mathrm{~cm}$ achieved a higher efficiency than the ones obtained with a drip irrigation system laid on the soil surface. This finding was explained by the fact that SDI allowed to uniform soil moisture, minimize the evaporative loss and delivery water directly to the plant root zone which increases use efficiency and yield.
According to the statistical comparisons in fact, the leaf area, the number of fruits per plant, as well as the crop yield obtained on SDI treatment, resulted significantly higher $(\mathrm{P}=0.05)$ than the corresponding measured on DI treatment. The better performance associated to SDI compared to DI, was due to the minor evaporation losses from the soil surface and consequently higher irrigation water use efficiency. When the drip laterals are buried, the wet bulbs in the soil induce the concentration of roots around the points where water is applied. Moreover, according to Shani and al. (1996) water infiltration occurs only in the soil volume surrounding the emitters, which is smaller than total soil volume of irrigated field. This result was confirmed by means of a scenario analysis performed with Hydrus-2D model, after the preliminary comparison between measured and simulated soil water contents at different depths and distances from the emitter (Ghazouani et al., 2015). Hanson and May (2007) tested the effects of different 
dripline positions on crop yield and quality of tomatoes crop. Based on their experiment, the Authors observed that higher yield and yield components can be obtained with buried drip laterals compared to furrow laterals. Patel and Rajput (2007), during three years of experiments in which investigated the effects of five installation depths on potato crop yield, evidenced that placing the driplines on soil surface or at 5 $\mathrm{cm}$ depth, determines evaporation losses due to the upward water movement up to $21.5 \%$ higher than the those obtained with dispending pipes installed at lower depths. Even Camp (1998) stated that SDI systems allow the reduction of evaporation losses and deep percolation, as well as the complete elimination of surface runoff.

\section{Conclusion}

This study investigated on the effect of subsurface drip irrigation, in comparison with drip irrigation, on water content and agronomic parameters of eggplants. Results evidenced that soil water contents were higher under subsurface irrigated treatment, as a consequence of lower losses by evaporation. Moreover, leaf area, number of fruits per plant, as well as the crop yield obtained on Subsurface drip irrigation, resulted significantly higher $(\mathrm{P}=0.05)$ than the corresponding measured on DI treatment. Results of that study demonstrated that, under semiarid climate, it is recommended to adopt buried laterals rather than traditional drip irrigation, to minimize water loses by the climatic demand, which is usually high under such environment. However, further experiments have to be carried out to investigate on the best drip line depth allowing maximizing water use efficiency.

\section{Conflict of interest}

The authors declare that there is no conflict of interest.

\section{Reference}

Allen, R. G.; Pereira, L. S.; Raes, D.; Smith, M. Crop evapotranspiration: Guidelines for computing crop water requirements. Rome: FAO, 1998. (FAO Irrigation and Drainage, 56).

ASAE-American Society of Association Executives. Standards EP405.1 FEB03 Design and Installation of Microirrigation Systems. St. Joseph, Michigan: ASAE, 2005.

Camp, C. R. Subsurface drip irrigation: A review. Transaction of the American Society of Agricultural Engineers, v. 41, no. 5, p. 1353-1367, 1998.

Douh, B.; Boujelben, A. Effet du système d'irrigation goutte à goutte souterrain sur une culture d'aubergine. Séminaire international, Exploitation des ressources en eau pour une agriculture durable. Hammamet-Tunisie 21 et 22 novembre, in Abstract book, p. 70, 2007.

Dukes, M. D.; Scholberg, J. M. Soil moisture controlled subsurface drip irrigation on sandy soils. Applied Engineering in Agriculture, v. 21, no. 1, p. 89-101, 1995.

Ghazouani, H.; Douh, M. B.; Autovino, D.; Amel, M. B.; Rallo, G.; Provenzano, G.; Boujelben, A. Optimizing subsurface dripline installation depth with Hydrus 2D/3D to improve irrigation water use efficiency in the Central Tunisia. International Journal of Meteorology and Quality Engineering, v. 6, p157-166, 2015.

Hanson, B.; May, D. Effect of subsurface drip irrigation on processing tomato yield, water table depth, soil salinity, and profitability. Agriculture Water Management, v. 68, p. 117, 2003.

Lamm, F. R.; Trooien, T. P. Subsurface drip irrigation for corn production: A review of 10 years of research in Kansas. Irrigation Sciences, v. 22, no. 3, p. 195-200, 2003.

Mailhol, J. C. Contribution à la maîtrise de l'irrigation et de ses impacts. Mémoire d'Habilitation à Diriger des Recherches, UR Irrigation Cemagref Montpellier, 2005. p. 18. 
Patel, N.; Rajput, T. B. S. Effect of drip tape placement depth and irrigation level on yield of potato. Agricultural Water Management, v. 88, p. 209-223, 2007.

Ruskin, R. Subsurface drip irrigation and yields. Corte Madera: Geoflow Inc., 2009.

Shani, U.; Xue, S.; Gording Kats, R.; Warrick, A. W. Soil limiting flow from subsurface emitters. I: Pressure measurements. Journal of Irrigation and Drainage Engineeing, v. 122 , no. 5, p. 291-295, 1996. 